\title{
Zapożyczenia leksykalne w cyklolekcie
}

\section{Lexical loans in Polish cycling sociolect}

\author{
Stefan Wiertlewski \\ SZKOŁA JĘZYKOWA, UNIWERYTET IM. ADAMA MICKIEWICZA, \\ UL. GRUNWALDZKA 6, 60-780 POZNAŃ \\ wiertl@amu.edu.pl
}

\begin{abstract}
There is an abundance of loanwords (especially English) in Polish cycling sociolect. After a presentation of basic facts on the different types of borrowings (lexical loans, semantic loans and loan translations), about 600 English lexical loans divided into semantic classes (e.g. cycling disciplines, riders, equipment) are analyzed in the article. This is accompanied by a discussion of the most striking characteristics of their graphic, phonological, morphological and semantic adaptation into the Polish language.
\end{abstract}

Zapożyczanie stanowi jeden ze sposobów wzbogacania zasobu leksykalnego języka ogólnego i jego odmian. Poniżej przedstawię kilkaset jednostek obcego pochodzenia, z których najliczniejszą grupę stanowią anglicyzmy. Angielskie pożyczki leksykalne podzielę na pola znaczeniowe oraz skomentuję najbardziej charakterystyczne cechy związane z ich adaptacją graficzną, fonologiczną, morfologiczną i semantyczną w języku polskim. Natomiast socjalną odmianę języka używaną $w$ szeroko pojętym i zróżnicowanym środowisku kolarskim nazywam cyklolektem.

O specyfice cyklolektu, podobnie jak innych socjolektów, decyduje leksyka, gdyż jego składnia jest $\mathrm{w}$ zasadzie identyczna $\mathrm{z}$ zasadami gramatycznymi obowiązującymi w polszczyźnie ogólnej. Za Ożdżyńskim (1970:10) przyjmuję, że leksyka przedstawianej odmiany języka dotyczy zwłaszcza ruchów i czynności związanych z jeżdżeniem na rowerze (np. grindować, wyrantować), sprzętu i jego komponentów (np. amor, aero, ass saver, blat, dropper, duracz, espedy, fatbike, full, karboniak, manetka, treningówka), osób jeżdżących na rowerze (np. downhillowiec, elita, 
grandtourowiec, sprinter), konkurencji kolarskich (np. dual slalom, keirin, scratch, trial, XC), wyścigów (np. finisz, klasyk, monument, neutralizacja, start, ultramaraton, World Tour), miejsc związanych $\mathrm{z}$ jeżdżeniem (np. bike park, hopka, rock garden, singletrack, szuter, welodrom), konserwacji i naprawy roweru (np. lightowanie, szprychować), ubioru (np. lycra, pampers), sposobu odżywiania, w tym przyjmowania zakazanych środków (np. epo, izo, żel), metod treningowych (np. interwat, tempówka), klubów i grup kolarskich (np. profi, protourowy), kontuzji i wypadków (np. faceplant, OTB, szlifki) oraz wartości preferowanych w omawianym środowisku (np. amator, gadżeciarz).

Wszystkie przywołane powyżej przykłady są zapożyczeniami leksykalnymi z języków obcych lub ich słowotwórczymi derywatami (traktuję je jako odrębne jednostki), przy czym większość to leksemy swoiste, a tylko niektóre spośród nich mają charakter wspólnoodmianowy (zob. Markowski 1992: 10). Ich zasięg nie jest ograniczony wyłącznie do kolarstwa czy innych języków sportu, ale obecne są one także w polszczyźnie ogólnej - ta właściwość dotyczy również części przykładów znajdujących się poniżej. Poddany tutaj analizie materiał językowy w ponad $97 \%$ pochodzi z mojej własnej, gromadzonej od kilkunastu lat kartoteki (o jego źródłach piszę np. w: Wiertlewski 2016: 145 - 147) i nie bywał zasadniczo uwzględniany przez autorów zajmujących się problematyką kontaktów językowych (por. np. Mańczak-Wohlfeld 1994 i 2010). Pozostałe kilka procent przykładów pochodzi z następujących publikacji: Bańko 2005, Łaziński 2008 i Mańczak-Wohlfeld 2010, ale nawet i te w znacznej mierze są swoistymi neosemantyzmami, których kolarskie odniesienia w przywołanych źródłach nie zostały odnotowane. Część przykładów pojawiła się w mojej wcześniejszej publikacji (Wiertlewski 2006), ale w przeważającej mierze jest to materiał nowy lub stosunkowo nowy, masowo absorbowany przez cyklolekt, co $\mathrm{w}$ pewnym stopniu potwierdza przedstawiony przez Witalisz (2016:27) wykres pokazujący, że liczba anglicyzmów w języku polskim w ostatnich dziesięcioleciach gwałtownie wzrosła.

Otóż cyklolekt, jak wspomniałem, podobnie jak inne środowiskowe odmiany polskich socjolektów sportowych, jest w znaczącym stopniu nasycony słowami obcego pochodzenia (por. Mańczak-Wohlfeld 1994:151, Ożdżyński 1970:12). Najwięcej spośród nich pochodzi z języka angielskiego, co w dużej mierze związane jest $\mathrm{z}$ historią sportu nowożytnego, i tymi zajmę się bardziej szczegółowo w dalszej części tekstu. Warto jednak na początek dla ukazania pełniejszego obrazu analizowanego socjolektu przywołać najbardziej charakterystyczne zapożyczenia różnego typu dotyczące roweru i jazdy na rowerze pochodzące $z$ innych niż angielski języków. Jak zobaczymy, niektóre z nich funkcjonują również w polszczyźnie ogólnej, ale w interesującym nas socjolekcie duża część z nich uległa neosemantyzacji, przyjmując specyficzne środowiskowe znaczenia i tylko te (wraz z regionalizmami, np. hample, rajfa) objaśnię.

Zacznijmy od całkiem licznych pożyczek niemieckich, z których niektóre są używane tylko regionalnie: banda („wyprofilowana część 
zakrętu, nasypu, która pozwala na przejazd łuku pod pewnym kątem”), belka („część ramy roweru”), blok („element wkręcany w obuwie, w który wpina się pedał zatrzaskowy”), centrować („regulować naciąg szprych w celu wyprostowania koła”), blat („największa zębatka z przodu roweru”), bremze („hamulce”), bruk („wyścig na nierównej nawierzchni z kamieni”), cyngle („dźwignie zmiany biegów”), cyrkiel („zadrapanie na nawierzchni, gdy podczas pokonywania zakrętu zahaczy się pedałem o podłoże”), defekt, dynamo, fartuch („ochraniacz dętki”), flak („przebita dętka”), grat (,zniszczony rower”), hak („zakończenia przedniego i tylnego widelca, do których montuje się przerzutki i koła”), hample („dźwignie hamulców”), hamulec, hebel („dźwignia hamulca”), hetm („kask”), inbus („rodzaj klucza o przekroju sześciokątnym”), ircha, kapsel („oczko w obręczy koła”), kibic, kielnia („kierownica w rowerze zjazdowym”), klamka („dźwignia hamulca”), klamkować („operować dźwigniami hamulców”), klamot („kiepski rower”), klocek („wypukły element opony”), koks („środki dopingujące”), kotnierz („zgrubienie na bocznych ściankach utrzymujące oponę w obręczy”), korba („dźwignia, do której przymocowane są pedały”), linka („cięgno hamulca lub przerzutki”), ładować (,jechać z całych sił”), maszyna („rower”), mewa („typ kierownicy”), mufa („stalowy łącznik rur w węzłach ramy”), nit, nypel („nakrętka łącząca obręcz ze szprychą”), pana („przebita dętka”), premia („nagroda punktowa np. na lotnym finiszu”), profi („kolarz zawodowy”), pudto („podium”), rafka („obręcz koła”), rajfa („obręcz koła”), rama („szkielet roweru”), rant („formacja kolarzy walczących z bocznym wiatrem”), runda („zamknięty odcinek dookoła którego ścigają się kolarze”), stal, spurt („sprint, ucieczka”), szelki („rozciągnięty peleton”), szlauch („dętka”), szlify („obtarcia naskórka w wyniku upadku”), szmelc („kiepski rower”), szpica („czub peletonu”), szpilka („szybkozamykacz”), szpryca („przyspieszenie”), szprycha, sztajfa („stromy podjazd”), sztyca („wspornik siodła”), sztywny („stromy”), szutrówka („rower szosowy do jazdy po szutrach”), ściana („stromy podjazd”), śruba, śrubkować („majsterkować przy rowerze”), tarcza („zębatka przednia”), tarczówka (,rower wyposażony w hamulce tarczowe”), torpedo („tylny hamulec uruchamiany ruchem pedałów do tyłu”), wachlarz („formacja kolarzy walczących z wiatrem i zazwyczaj zajmująca całą szerokość szosy”), wat (,jednostka, w której mierzy się siłę kolarza), wentyl.

Mniej liczna jest grupa zapożyczeń francuskich, takich jak akrobacja („trik wykonywany na rowerze”), amator („kolarz nie będący zawodowcem”), baton („przednie koło w rowerze czasowym”), beret („kask”), bicykl, bidon, bileter („ostatni zawodnik na wachlarzu pilnujący, aby nie przyłączył się ktoś z konkurencji”), bufet („strefa, w której zawodnicy otrzymują jedzenie”), cyklista, debiut, dyrektor sportowy („directeur sportif”), domestique („kolarz pomagający liderowi drużyny”), ekipa, elita („kolarze z kategorii wiekowej seniorów”), etap („odcinek wyścigu”), etapowiec („kolarz specjalizujący się w wyścigach wieloetapowych”), kask, manetka („dźwignia zmiany biegów”), manetkować („obsługiwać dźwignie przerzutki”), medal, palmares („spis osiągnięć kolarza”), peleton, prolog 
(„krótki etap przed wyścigiem wieloetapowym”), rampa („specjalny tor o przekroju bocznym rynny do wykonywania akrobacji"), rezultat, rywal, sezon, szosa („rower wyścigowy”), tour („wyścig”), welocyped, welodrom („tor kolarski, obecnie przeważnie kryty”), żel (,środek odżywczy”), żótta koszulka („maillot jaune”).

Z kolei, zapożyczenia włoskie to np. duet („dwóch kolarzy”), finat, gregario, („pomocnik lidera drużyny”), grupetto („grupka kolarzy jadących z tyłu”), solo, solista („kolarz jadący samotnie”), stranieri („obcokrajowcy w ekipie kolarskiej”), tempo, tempówka (,jazda z wysoką prędkością”), tifosi („kibice”), velostrada („droga rowerowa wyższej kategorii”). Z laciny natomiast pochodzą m.in. akcja („np. próba ucieczki z peletonu”), amortyzator, amor („zawieszenie roweru”), aparat („przerzutka”), eliminacja, ekstremalista („kolarz uprawiający np. zjazd”), interwat („pokonywanie na przemian odcinków trasy $\mathrm{z}$ bardzo wysoką intensywnością, po której następuje faza wolniejsza”), grawitacja („rodzaj kolarstwa górskiego rozgrywany na stromych stokach”), grawitowiec ("kolarz uprawiający kolarstwo grawitacyjne"), grawiciarstwo, junior („kategoria wiekowa kolarza”), kadencja („liczba obrotów korbą na minutę”), klasyfikacja, konduktor („ostatni zawodnik na wachlarzu pilnujący, aby nie przyłączył się ktoś z konkurencji”), kondycja („stan sprawności fizycznej i wytrzymałości”), konkurencja („dyscyplina kolarska”), kontra („przeciwnakrętka”), kontuzja, kwadrat („oś suportu zakończona wpustem do mocowania korby”), manifest („karta, na której potwierdza się zaliczenie poszczególnych punktów wyścigu kurierów rowerowych”), modulacja („możliwość stopniowego operowania hamulcem”), punkt, transfer („zmiana drużyny przez kolarza”), triumfator. Pojedyncze pożyczki pochodzą również np. z czeskiego (mistrz), greki (maraton - „długi wyścig kolarski”, taktyka), hiszpańskiego (venga, venga - „idziesz, naprzód”), japońskiego (keirin - „wyścig na torze za motocyklem”), norweskiego (slalom) czy węgierskiego (puchar).

Zanim przejdę do bardziej szczegółowego omówienia anglicyzmów leksykalnych w polskim cyklolekcie z podziałem na pola znaczeniowe, warto krótko przypomnieć o głównych rodzajach pożyczek (ograniczę się tutaj wyłącznie do przykładów pochodzenia angielskiego). Otóż najczęściej wyróżnia się 3 kategorie zapożyczeń (por. Haugen 1950): leksykalne, semantyczne i strukturalne.

Zapożyczeniami leksykalnymi, gdzie przedmiotem zapożyczenia jest zarówno znaczenie, jak i forma wyrazu są np. alleycat („wyścig kurierów rowerowych w otwartym ruchu drogowym"), camelback ("bukłak"), damper („tylny amortyzator”), downhill („konkurencja polegająca na najszybszym zjechaniu ze wzniesienia”), drop („uskok”), fatbike („rower na bardzo szerokich oponach”), flatland (,akrobatyka na rowerze”), flow („płynność jazdy”), trial („dyscyplina kolarstwa górskiego polegająca na pokonywaniu toru przeszkód bez stawiania stóp na ziemi”), tubeless („ogumienie bezdętkowe”), wheelie (,jazda na tylnym kole z pedałowaniem”). 
W pożyczkach semantycznych pod wpływem języka obcego zapożyczane jest nowe znaczenie wyrazu, które zostaje przypisane do formy już istniejącej, która z kolei może być wcześniejszą pożyczką, także z innego niż angielski języka, np. agresywny - aggressive („zdecydowany”), ciągnąć - pull (,przewodzić stawce kolarzy samemu nie mając ochrony przed wiatrem”), dywizja - division („kolarski odpowiednik ligi rozgrywkowej w grach zespołowych”), elita - elite („kategoria wiekowa zawodników seniorzy”), kaseta - cassette („zestaw zębatek zamocowanych na piaście z wolnobiegiem”), klasyk - classic („wyścig jednoetapowy”), korona - crown („część amortyzatora łącząca golenie górne”), mielić - grind („jechać na wysokich przełożeniach, np. podczas pokonywania podjazdów”), miska cup („łożyska mechanizmu sterowego”), monument - monument („wielki wyścig klasyczny, np. Mediolan - San Remo"), neutralizacja neutralization („podjęta przez sędziów decyzja, że kolarze na trasie nie mają się ścigać, np. z powodu złych warunków pogodowych”), pijawka - leech („kolarz jadący na końcu grupki, korzystający z osłony przed wiatrem, ale nie wychodzący na prowadzenie”), pociąg - train („formacja kolarzy z jednej drużyny, jadących jeden za drugim i narzucająca peletonowi wysokie tempo w celu uzyskania dla swojego lidera korzystnej pozycji do ataku przed metą"), pracować - work (,jechać, wymieniając się na prowadzeniu na czele peletonu”), skakać - jump (,próbować odjechać od peletonu przez gwałtowne zwiększenie tempa”), ściana - wall („bardzo stromy podjazd”), tańczyć - dance (,jechać na stojąco kołysząc się na boki”), ugotowany cooked („zmęczony, jadący ostatkiem sił”), widelec - fork („rozgałęziona część łącząca koło z ramą”), wypompowany - pumped („zmęczony, jadący ostatkiem sił”).

Natomiast w zapożyczeniach strukturalnych przejmowana jest, czyli kalkowana, struktura słowotwórcza wyrazu, podczas gdy jego substancja pozostaje polska. Tego typu zapożyczenia są najmniej oczywiste i najtrudniej rozpoznawalne, choć w cyklolekcie jest ich całkiem sporo, np. bottom pull - dolny ciąg („linka przerzutki poprowadzona jest pod osią suportu”), brake levers - dźwignie hamulca („klamki hamulcowe”), bullhorn bar - bycze rogi („kierownica używana w wyścigach na czas”), bunny hop - skok króliczy (,jednoczesne oderwanie od podłoża obu kół”), chain whip - bacik („narzędzie do odkręcania koronek wielotrybów”), crank arm - ramię korby („dźwignia, do której przymocowany jest pedał”), critical mass - masa krytyczna („,zorganizowane przejazdy grup rowerzystów przez centra miast”), cycling officer - oficer rowerowy („urzędnik odpowiedzialny za ruch rowerowy w mieście”), egg beater - ubijaki („typ pedałów zatrzaskowych”), flying finish - finisz lotny („finisz na premii w trakcie wyścigu”), froglegs - zabie udka („typ pedałów zatrzaskowych”), full suspension - petne zawieszenie (,amortyzacja przedniego i tylnego koła”), general classification - klasyfikacja generalna („końcowa kolejność zawodników”), granny gear - babcine biegi (,jazda na małej zębatce z przodu i dużej z tyłu lub trójtarcz w rowerze szosowym”), king of the mountain - król gór („kolarz najlepiej jeżdżący po górach”), mark of the novice - tatuaż nowicjusza („Ślad łańcucha odciśnięty na prawej łydce”), 
mountain biking - kolarstwo górskie („konkurencja kolarska”), oil chamber - komora olejowa („część amortyzatora”), pilot of the race - pilot wyścigu („osoba jadąca w pojeździe mechanicznym na czele wyścigu”), open window effect - efekt otwartego okna („wzmożona podatność na infekcje po intensywnym treningu lub wysiłku”), point classification - klasyfikacja punktowa („kolejność zawodników w zależności od liczby punktów zdobytych na premiach”), rock garden - ogródek skalny („miejsce, zwykle na zjeździe, usłane dużą ilością kamieni różnej wielkości”), rear triangle tylny trójkąt („część ramy roweru”), seat tube - rura podsiodtowa („część ramy roweru, w którą mocuje się wspornik siodła”), sharp pace - ostre tempo („szybka jazda”), sit on the wheel - siedzieć na kole (,jechać za kolarzem jadącym z przodu i korzystać z ochrony przed wiatrem”), snake bite - ukąszenie węża („charakterystyczne przebicie dętki, np. po najechaniu na krawężnik”), miękki ogon - soft tail („tylna amortyzacja”), steer tube rura sterowa („przytwierdzona do niej jest kierownica”), suspension zawieszenie („amortyzacja roweru”), top tube - rura górna („część ramy roweru”), track cycling - kolarstwo torowe („dyscyplina rozgrywana na kilkusetmetrowych torach, często krytych”), top pull - górny ciąg („linka przerzutki poprowadzona jest wzdłuż górnej rury ramy"), water carrier woziwoda („kolarz dowożący bidony pozostałym członkom drużyny”), wheel base - baza kół („rozstaw osi kół”). Dodam, że dwa ostatnie rodzaje zapożyczeń są generalnie zbadane w stosunkowo małym stopniu, a tekstami traktującymi o tych zagadnieniach godnymi polecenia są np. książki Witalisz (2007, 2015, 2016), które jednak nie przywołują leksyki z obszaru tutaj omawianego.

W tym miejscu warto jeszcze zauważyć, że nie zawsze zapożyczenia wchodzą do polszczyzny w pełnym zakresie znaczeniowym, jakie mają w języku oryginalnym. Dobrze ilustrują to zjawisko słowa bike i biker. To pierwsze, w angielskim nazywa nie tylko rower ale także motocykl. Natomiast drugie, odnosi się do rowerzysty, motocyklisty a także członka gangu motocyklowego. Obydwa te zapożyczone leksemy powszechnie funkcjonują w polskim cyklolekcie wyłącznie w pierwszych znaczeniach. Inna jest natomiast sytuacja w przypadku słowa rower, także pochodzącego $\mathrm{z}$ angielskiego. W angielskim oznacza ono wędrowca, ewentualnie włóczęgę, a współcześnie także pojazd księżycowy lub marsjański. Wyraz ten (będący derywatem w języku angielskim) także był nazwą firmową (Rover) pojazdów, zwanych wcześniej bicyklami, które cieszyły się znaczną popularnością na ziemiach polskich. Ostatecznie nazwa firmowa stała się z czasem nazwą rodzajową interesujących nas tutaj jednośladów. Dodam, że także leksem sport ma w języku angielskim znacznie szersze znaczenie niż w polszczyźnie, gdyż obejmuje także np. wędkarstwo czy myślistwo, a również np. oznacza hazardzistę. W przywołanych powyżej przypadkach leksemów polisemicznych mamy do czynienia ze zwężeniem znaczeniowym, czyli adaptacją semantyczną pożyczek, co będzie również dotyczyło części prezentowanych poniżej przykładów (np. cross, fast, fat, flat, full, jump, pro, street). 
Obecnie przedstawię obszerny zbiór angielskich zapożyczeń leksykalnych i ich derywatów morfologicznych funkcjonujących $\mathrm{w}$ cyklolekcie z podziałem na wybrane pola znaczeniowe, przy czym część z nich jest adoptowana do polskiej pisowni i wymowy. Ponieważ niektóre $z$ nich występują głównie w liczbie mnogiej, tę ich właśnie formę przywołam poniżej. Znaczna część analizowanego materiału językowego ma charakter terminologiczny, co stanowi o jego nie intencjonalnej stosunkowo niskiej komunikatywności poza środowiskiem kolarskim.

Zacznijmy od obszernego i nieustannie powiększającego się pola obejmującego nazwy typów rowerów, co w części jest wynikiem działań marketingowych. Są tu (objaśnienia w przypadku grup synonimów podaję na końcu danej serii) np. aerobike, („rower aerodynamiczny”), all-mnt, all mountain, all-muntainowiec, $A M$, („wszechstronny rower górski”), allroad, all-rounder, $A T B$, („rower wszechstronny”), BMX, beemiks („rower na małych kołach do akrobacji”), bike („rower”), carbon, carboniak, karbon, karbonówka („rower z kompozytów węglowych”), cargobike („rower towarowy”), chopper („rower o niskim zawieszeniu”), city bike („rower miejski”), cross bike, kross, krossówka („rower przełajowy”), cruiser („rower o niskim zawieszeniu”), custom bike („rower wykonany na zamówienie”), dirt bike, dirtówka („typ roweru górskiego przeznaczony do ewolucji w terenie”), dualówka („rower do wyścigów w terenie rozgrywanych parami”), e-bike („rower ze wspomaganiem elektrycznym”), ekorower („rower ze wspomaganiem elektrycznym”), ED, enduro, endurówka („rower do jazdy w górach”), endurance („rower szosowy do pokonywania długich dystansów”), fat, fatbike („rower na bardzo szerokich oponach”), fitnessbike („rower szosowy z prostą kierownicą”), fixie (,rower bez wolnobiegu”), fourcrossówka („rower do wyścigów czwórkami w terenie”), FR, freeride, freerajdówka („rower posiadający różne cechy rowerów terenowych”), full („rower z pełnym zawieszeniem”), fun bike, funbike („rower dla osób stawiających pierwsze kroki w różnych odmianach kolarstwa terenowego”), ghost bike („pomalowany na biało rower ustawiany w miejscach, gdzie zginęli rowerzyści przejechani przez samochody"), gravel, gravelówka, grejwel, grejwelówka (,rower szosowy do jazdy po szutrach”), handbike („rower napędzany ruchem rąk”), HT, hard tail („rower bez tylnej amortyzacji”), kid („rowerek dziecięcy”), lowrider („typ roweru o niskim zawieszeniu”), makrokesz („tani rower z marketu”), pedalec („rower ze wspomaganiem elektrycznym”), pushbike („rowerek dziecięcy wprawiany w ruch przez popychanie"), singiel, singlespeed (,rower bez przerzutki, ale z wolnobiegiem”), speedrower („rower do ścigania się na torze żużlowym”), tandem („rower dwuosobowy”), trekking, trekkingowiec, trekkingówka („rower do wypraw turystycznych”), trialówka („rower do pokonywania toru przeszkód w terenie”), treningówka („rower treningowy”), twentyniner („rower na kołach o średnicy 29 cali”), upgrad („rower z ulepszeniami”), uphillówka („rower do pokonywania podjazdów w górach”).

Obszerna jest również kategoria obejmująca kolarzy różnych specjalności i ludzi z kolarstwem związanych. Ponieważ w części są to 
leksemy pochodzące od jednostek, których znaczenia opisałem powyżej, poniżej ograniczę się do objaśniania pozostałego materiału. Na kolejne pole semantyczne składają się np.: all rounder („kolarz wszechstronny”), backpackingowiec („podróżujący rowerem z sakwami”), batman („rowerzysta jeżdżący po zmroku bez oświetlenia”), beemiksiarz, BMXiarz, bmxowiec, bike commuter („osoba dojeżdżająca rowerem np. do pracy”), bike fitter („osoba dopasowująca rower do kolarza”), bikeholic („uzależniony od jazdy na rowerze”), biker, bikerka, bikerzyca („rowerzystka”), crosscantrowiec, crossiarz, krossiarz, courier, kurier, cyklmuter („osoba regularnie dojeżdżająca rowerem, np. do pracy”), champion („mistrz”), dirtowiec, dirtjumper, dirtman („zawodnik wykonujący ewolucje na torach ziemnych”), doper („zażywający niedozwolone środki"), dopingowicz, downhillowiec, dualowiec, $e$ bike'owiec, e-bikowiec, ekspro („były kolarz zawodowy”), elita, endurowiec, fatbikowiec, finiszer („kolarz kończący wyścig”), flatlander, flatlandowiec, flaternik, flatowiec (,wykonuje akrobacje na płaskich powierzchniach”), fourcrossowiec, freerider, freeridowiec, gadżeciarz („kolarz przesadnie przypisujący wagę do marek komponentów roweru”), gigowiec („zawodnik startujący na najdłuższych trasach maratonowych"), grandtourowiec („uczestnik wyścigów wieloetapowych”), gravelista, gravelowiec, handbiker, hardcorowiec (,kolarz wybierający najbardziej wymagające trasy”), ironbiker („kolarz pokonujący trasy ekstremalnie długie i trudne”), leader, localesi („miłośnicy kolarstwa ekstremalnego z danej miejscowości”), masters („kolarz w wieku średnim lub zaawansowanym”), mountainbiker, mountainbikowiec, MTBowiec, niepros („kolarz amator”), PRO, pros („kolarz zawodowy”), rajder, rider, rajderka, riderka („kolarz, kolarka”), semi-pro („zaawansowany kolarz amator”), stoker („siedzący z tyłu na tandemie”), streeciarz, streeter, streetowiec („wykonuje ewolucje na murkach, balustradach, krawężnikach itp.”), team („drużyna”), trailowiec, trener („osoba szkoląca kolarzy”), trailsowiec, tricker („kolarz wykonujący akrobacje”), ultras, ultrabiker („kolarz pokonujący bardzo długie dystanse”), uphiller, uphillowiec.

W podkategorii dotyczącej różnych typów aktywności na rowerze, konkurencji kolarskich i dystansów na maratonach znajdują się m.in.: advanture racing, $A R$ („ekstremalny rajd przygodowy”), alley cat, alleycat, alleyket, big air („wykonywanie akrobacji wysoko nad ziemią”), bikejoring („pies lub psy połączone linką ciągną rower”), bikejumping („skoki na rowerze”), bikemaraton („wyścig rozgrywany w terenie”), bikepacking („wyprawy rowerem z sakwami”), bobrun-biking („wyścigi rowerów na kołach z kolcami po torach bobslejowych"), CC, cross, kross, crosscountry, cyclocross, XC, XCE, XCM, XCO („wyścig przełajowy”), chicken line („objazd przeszkody”), cycle-ball („zawodnicy na rowerach grają popychając piłkę”), coffee ride („wolna przejażdżka z przerwą na kawę”), DJ, dirt jumping („konkurencja kolarska polegająca na wykonywaniu skoków na torach ziemnych”), downhill, $D H$, drafting (,jazda za kolarzem w celu zmniejszenia oporu powietrza, zwana też podciąganiem”), DNF („nie ukończył wyścigu”), drifting („wchodzenie w zakręty z poślizgiem”), dual 
slalom, DS, enduro, flatland, four cross, 4 cross, FR, freeride, gold sprint („wyścig rozgrywany przez kurierów rowerowych”), full, giga, half („dystanse na maratonach rowerowych”), graveling (,jazda po szutrach”), grindowanie (,jeżdżenie na pegach po barierkach”), helibiking („dolot helikopterem na trudno dostępne miejsce jazdy rowerem"), hucking („skakanie wielkich dropów”), indoor cycling (,aerobic na rowerach”), madison („konkurencja w obrębie kolarstwa torowego”), mini, maxi, mega („dystanse na maratonach rowerowych”), mountainbiking, on sight („ściganie bez wcześniejszej znajomości trasy”), open („wyścig, w którym obok zawodowców starują amatorzy”), quarter („rampa, na której wykonuje się akrobacje na rowerze”), rege („wolna przejażdzka”), roadtripping („podróżowanie rowerem”), scratch („konkrencja w obrębie kolarstwa torowego”), self-support („wyścig, podczas którego zawodnicy muszą sobie radzić sami z ewentualnymi kłopotami”), skid („technika hamowania tylnym kołem na rowerze bez wolnobiegu powodująca wpadnięcie w kontrolowany poślizg”), slow biking („spokojna jazda”), skill („umiejętność wykonywania trudnych manewrów”), speedbiking, spinning („zajęcia fitness na rowerach stacjonarnych”), cycle speedway („wyścig rowerowy na torze żużlowym”), sprint, street, tracklocross (,jazda rowerem bez przerzutek i wolnobiegu w terenie”), trening, trial, triathlon („konkurencja składająca się z pływania, biegu i jazdy rowerem”), TT, time trial (,jazda na czas”), vert, wert („ewolucje rowerem na rampie”), world tour („cykl najważniejszych wyścigów szosowych”). Tutaj pewnie powinny również znaleźć się nazwy licznych imprez kolarskich dla amatorów przyjmujące formę złożeń w rodzaju Bike Maraton, Bydgoszcz Cycling Challenge, Dare 2B MTB Maraton, Downhill City Tour, Monteria FAT Bike Race, Poland Bike Maraton, Race Through Poland, Sudety MTB Challenge, Tatra Road Race, Trophy Maja Race itp., gdzie mamy do czynienia z zapożyczaniem modeli strukturalnych (Witalisz 2016: 144 -148). Osobną kwestią pozostaje, czy jest to rzeczywiście konieczne. Być może organizatorom imprez chodzi o podniesienie prestiżu wyścigów przez nadanie im nazw angielskich, budzących ich zdaniem pozytywne konotacje. Dodam, że zapożyczeń używa się również w prześmiewczych nazwach wyścigów niskiej rangi, np. Remiza Tour czy Tour de Stodota.

Następna z rozważanych podkategorii obejmuje leksykę dotyczącą budowy roweru, jego elementów oraz dodatkowego wyposażenia roweru i kolarza. Znajdują się w niej np. A-head ("typ łożyska sterowego montowany w kierownicy”), anti-rise („mechanizm przeciwdziałania podnoszeniu się łańcucha”), anti-squat („mechanizm przeciwdziałania osiadaniu zawieszenia podczas przyspieszania”), ass-saver („lekki błotnik szosowy montowany pod siodłem”), barbag („torba montowana na kierownicy”), barendy, barendsy („zakończenia kierownicy”), booster („element o kształcie podkowy zapobiegający rozciąganiu ramy podczas hamowania”), bottom-out („regulacja kompresji w końcowej fazie ugięcia amortyzatora, zapobiega dobiciu”), burping („popuszczanie powietrza przy krawędzi obręczy koła podczas pokonywania zakrętu”), bushguard („osłona zębatki”), camelback („bukłak z rurką umożliwiającą picie podczas jazdy”), 
cantilever, cantisy („hamulec obręczowy”), canting („nachylenie powierzchni buta względem osi pedału”), cartridge, kartridż („nabój wypełniony olejem odpowiedzialny za tłumienie lub sprężyna powietrzna w amortyzatorze”), chain dog, chain guide („napinacz lańcucha”, chain guard („osłona korby”), chainstay („mechanizm nie pozwalający przemieszczać się tylnej osi w rowerach z zawieszeniem”), chain suck („zakleszczenie łańcucha”), cleaty („bloki do wpinania butów w pedały zatrzaskowe"), crash replacement ("gwarancja wymiany uszkodzonych komponentów”), crossbar („poprzeczka w giętej kierownicy”), damper („tylny amortyzator, wahacz”), degreaser („odtłuszczacz smarów rowerowych”), dropper („sztyca teleskopowa”), dual control (,jedna dźwignia obsługująca przerzutkę i hamulec”), espedy, espedziaki („pedały zatrzaskowe”), fading („nagły spadek siły hamowania w wyniku przegrzania się okładzin w hamulcach”), flara („odgięcie końcówek kierownicy na zewnątrz”), flip flop („mostek z możliwością obracania o $180^{0}$ ”), frameset („kompletna rama rowerowa”), froglegsy („typ pedałów zatrzaskowych”), gear box („system przerzutek wewnętrznych”), gripy („chwyty kierownicy”), grip shift, gripshift („manetka obrotowa”), kompakty („kombinacja zębatek 50/34”), full face, full fejs („kask chroniący całą głowę”), FS, full suspension („pełne zawieszenie”), gusset („wzmocnienie rur”), headset („typ łożyska sterowego montowanego w kierownicy”), inmould („technologia wstrzykiwania pianki do skorupy kasku”), karkass („korpus opony”), kaseta (,zestaw trybów mocowany na piaście z wolnobiegiem”), kliki („pedały zatrzaskowe”), kord („oplot w oponie”), lemondka („nakładka na kierownicę szosową umożliwiająca oparcie łokci”), lock out („urządzenie blokujące amortyzator”), lobstery („rękawice trójpalcowe”), lockring („nakrętka pierścieniowa zabezpieczająca kasetę”), mariginal gains („podejście polegające na wprowadzaniu drobnych ulepszeń w treningu, stroju, rowerze kolarza tak, aby ich suma dawała przewagę nad konkurentami”), MIPS („zarządzanie energią uderzenia rotacyjnego w kaskach”), motodoping („ukryty w rowerze i niedozwolony silniczek wspomagający jazdę”), multitool („narzędzie zawierające wiele kluczy”), offset („odległość odsunięcia jarzma siodełka od osi wyznaczonej przez środek rury podsiodłowej”), oversized („rura sterowa o dużym przekroju”), pady („podłokietniki”), partsy („części rowerowe”), pedal bob („huśtanie roweru podczas przyspieszenia”), pedat („platforma na którą naciska się stopami, aby wprawić rower w ruch”), pegi („podnóżki przykręcane na końcówkach osi piast służące do wykonywania akrobacji”), piwot („oś obrotu hamulca”), platformówki, platformy („typ szerokich pedałów”), reach („długość ramy”), rocker („element łączący tłumik i rurki podsiodłowe wahacza”), rockring („dodatkowy pierścień montowany zamiast dużej koronki, chroniący zęby pozostałych przed uszkodzeniem podczas przejazdu przez przeszkody”), rotor („tarcza hamulcowa”), $S A G$ („ugięcie wstępne amortyzatora”), semi-kompakty („kombinacja zębatek 52/36”), semi-slick („opona z niedużym bieżnikiem”), serwis, serwisowanie („naprawianie i konserwowanie roweru”), shockboots („gumy lub neopreny osłaniające górne golenie amortyzatora przedniego”), 
SID („amortyzator powietrzny Rock Shoxa”), SIS („przerzutki niższej klasy firmy Shimano”), slick („gładka opona bez bieżnika”), sloping („obniżenie górnej rury ramy roweru”), SPD (,pedały zatrzaskowe”), stack („pionowa odległość od środka suportu do główki sterów”), $S T W$ („stosunek sztywności do wagi ramy”), suport („mechanizm korbowy”), TB („rury rowerowe mające trzy różne grubości ścianek”), tubless („opona bezdętkowa”), tublessowanie („montowanie opon bezdętkowych”), U-lock („zabezpieczenie roweru przed kradzieżą w kształcie litery U”), upsidedown („typ amortyzatora, w którym golenie górne i dolne zamieniono miejscami”), V-breaki, fatbrejki („typ hamulców szczękowych”), VPS („wirtualny punkt obrotu zawieszenia”), WS („rowery, stroje itd. przeznaczone dla kobiet").

Kolarstwa ekstremalnego i grawitacyjnego, miejsc jego uprawiania i rozmaitego typu przeszkód dotyczą m.in.: after party („przyjęcie po zawodach kolarstwa grawitacyjnego"), bank ("rampa, stromy zjazd"), before party („przyjęcie przed zawodami kolarstwa grawitacyjnego”), bike park („teren $\mathrm{z}$ przygotowanymi trasami do uprawiania różnych odmian kolarstwa, zwłaszcza górskiego”), B-line („dłuższy, ale bezpieczny objazd przeszkody”), chicken line, flowtrial („dłuższy, ale bezpieczny objazd przeszkody”), box („konstrukcja o kształcie prostopadłościanu do wykonywania akrobacji”), bowl („wyprofilowana konstrukcja do wykonywania akrobacji”), double, dable („podwójna przeszkoda”), drop („uskok”), flip-flop („skalna przeszkoda w kształcie stopy”), funbox („urządzenie o solidnej konstrukcji do wykonywania akrobacji, montowane często w skateparkach”), gap („szczelina, nad którą przelatuje się rowerem po wybiciu w powietrze”), half pipe („klasyczna rampa”), jam („zawody, pokazy na których wykonywane są akrobacje na rowerach"), jumpbox („konstrukcja do wybijania się w celu wykonania wyskoków”), northshore, northszor („drewniane lub stalowe kładki służące do zwiększania technicznej trudności tras, najczęściej ustawiane w lesie”), off-road (,jazda w terenie”), pumptrack („tor o specjalnej ukształtowanej falistej powierzchni i wyprofilowanych zakrętach”), quarterpipe („rodzaj rampy”), rock garden („trudny technicznie odcinek wyścigu poprowadzony przez rumowisko skalne”), roller („niewielkie wybrzuszenie terenu do wybicia się w powietrze”), single, singiel, single track („,wąska ścieżka w górach”), stepdowny („niewielkie uskoki”), step up („typ przeszkody”), trailpark („przygotowany teren do uprawiania kolarstwa górskiego”), trick, trik („akrobacja wykonywana na rowerze”).

$\mathrm{Z}$ powyższym bezpośrednio związane są nazwy trików i akrobacji wykonywanych na rowerze, jak np. backflip, backpivot, backwards, back yard, bar hop, barhop, boomerang, bunny, hopbar spin, crankflip, Elephant glide, endo, fakie, feeble, grind, flip, flipwhip, frame stand, frontflip, frontpivot, front yard, grind, icepick, manual, no foot, one footer, one hander, pedal kick, pedal up, peg manual, piwot, rocketair, roll back, seat grab, Roys, side hop, squeaker, steamroller, superflip, superman, surfing, tail, toothpick, wheelie, whip, $x$-grind, $x$-up, czy też ich połączenia, czyli combosy, kombosy. Ten ostatni leksem nazywa również technikę 
stosowaną w kolarstwie przełajowym, polegającą na zeskakiwaniu z roweru w czasie jazdy, biegnięciu i ponownym wskakiwaniu na rower.

Mniej obszerna natomiast jest grupa dotycząca odżywiania się, nastawienia psychicznego do jazdy oraz regeneracji, np. all in $i$ do przodu (,atak po najedzeniu się i zaspokojeniu pragnienia podczas wyścigu”), bikefitting („dopasowywanie roweru do kolarza”), carbosnacki („np. żele służące uzupełnieniu węglowodanów”), core („trening mięśni bioder, brzucha i lędźwi odpowiedzialnych za stabilizację kręgosłupa i wzmocnienie całej sylwetki”), epo („hormon stymulujący wydolność stosowany jako forma dopingu”), fixed mindset („sztywny, niezmienny sposób myślenia”), gainer („odżywka białkowo-węglowodanowa”), growth mindset („sposób myślenia nastawiony na rozwój sportowy”), izo, izotonic („napój izotoniczny zawierający m.in. elektrolity”), messlife („hasztag powszechnie używany przez jeżdżących na rowerach bez przerzutek i wolnobiegu, mający wyrażać ich awangardowy styl”), powerbar („baton energetyczny”), power nap („krótka drzemka podczas ekstremalnie długich, liczących nawet kilka tysięcy km wyścigów na czas), recovery („odżywka stosowana po wyścigu lub intensywnym treningu zawierająca głównie białko”), roller („wałek do autorozluźniania międzypowięziowego”), rolowanie („wałkowanie mające na celu autorozluźnienie międzypowięziowe”), stroju, np. bagy shorts („luźne spodenki kolarskie”), lycra, lajcra („tworzywo z którego wykonuje się obcisłe stroje kolarskie”), pampers („wkładka w spodenkach kolarskich”), czy wypadków, np. face plant (,upadek na twarz”), nutter („uderzenie górną rurą w krocze”), OTB („niekontrolowany przelot nad kierownicą").

Oddzielnie z kolei należy potraktować ekspresywne i zabawne najczęściej spolszczenia terminów i nazw angielskich czy też pseudoanglicyzmy, gdzie wykorzystuje się głównie, choć nie wyłącznie, podobieństwo fonetyczne słów, jak ma to miejsce w następujących przypadkach: afterka - after party, („przyjęcie po zawodach np. kolarstwa grawitacyjnego”), baniak - bunny hop (,jednoczesne oderwanie obu kół od podłoża”), belka („kask firmy Bell”), biforka („przyjęcie przed zawodami kolarstwa grawitacyjnego”), duracz i duraś („osprzęt szosowy z najwyższej grupy Dura Ace”), ketaj i ketajka („oświetlenie rowerowe Cat Eye”), dechowiec i dehowiec („kolarz uprawiający DH, czyli zjazd”), deorki („osprzęt szosowy z grupy Deore”), duszmeni („osoby duszące na pedały”), ęduro - enduro („konkurencja kolarstwa górskiego”), espedy i espedziaki („pedały zatrzaskowe”), geje - gay („pedały rowerowe”), grubas i thuścioch - fatbike („rower na bardzo szerokich oponach”), kamel - camelback („bukłak”), lefciak (,amortyzator jednogoleniowy Leftie”), PROsiak pro(„,kolarz zawodowy”), rudzielec („kask Rudy Project”), sztywniak - hard tail („rower bez zawieszenia”), trikasy - tricks („akrobacje wykonywane na rowerze). Tutaj też przynależą spolszczenia marek rowerów, np. Kołodziej Wheeler, Konina - Kona, Lawinka - Avalanche, Madonka - Trek Madone, Mangusta - Mongoose, Sekator - Sector, Skocina-Scott, Spec-Specialized. Jako osobną podkategorię potraktuję łącznie czasowniki powstałe na bazie angielskich zapożyczeń właściwych, gdzie proces adaptacji 
morfologicznej polega na dołączeniu rodzimego przyrostka oraz czasowniki derywowane od zapożyczeń właściwych, np. bicyklować, bikować, dirtować, draftować, driftować, dropować, dublować, flacić, flatlandować, gravelować, grindować (,jeździć na pegach np. po balustradach”), jumpować, klikać („wpinać pedały zatrzaskowe”), kurierować („wykonywać pracę kuriera rowerowego”), lajtować („zmniejszać wagę roweru poprzez montowanie lżejszych komponentów”), serwisować, slidować, sprintować, streetować, surfować (,jechać na stojąco ze stopami opartymi na górnej części ramy”), szejkować („czyścić zdemontowany łańcuch zanurzony $\mathrm{w}$ odpowiednim roztworze przez potrząsanie nim”), trialować, trikować („wykonywać akrobacje”), tublessować, upgradować (,ulepszać rower poprzez montowanie komponentów wyższej jakości”), uphillować, whipować („latać na rowerze bokiem").

Bez trudu można również wskazać adoptowane morfologicznie przez dodanie polskiego sufiksu przymiotniki w rodzaju allroadowy, bikerski, boostowy („wzmocniony”), commutingowy, crossowy, downhillowy, enduranceowy, flatlandowy, freereideowy, gravelowy, lycrowy, mountbajkowy, outdoorowy, racingowy, streetowy, teamowy, tracklocrossowy, trialsowy, tuningowy, wertowy, worldtourowy.

Jak wspomniałem wcześniej, w obrębie socjolektu rowerowego sytuują się również jednostki wspólnoodmianowe, jak np. rower, będący eponimem zapożyczonym z języka angielskiego, który w języku ogólnym ma tylko kilka derywatów (np. rowerzysta, rowerzystka, rowerowy, rowerek), natomiast w omawianej odmianie zarejestrowałem ich ponad 5o, nie odnotowywanych w słownikach języka polskiego (nie uwzględniam kolejnych zdrobnień czy też zgrubień), takich jak np. dorowerować („dojechać”), nieurowerowiony („nie posiadający roweru”), niezroweryzowany („nie posiadający roweru”), porowerkować („pojeździć na rowerze”), porowerzyć („pojeździć na rowerze”), prorowerowy, przedrowerowy, przerowerkować („przejechać pewien dystans"), przerowerować, rowerkować, rowerować, rowerowicz, rowerowiec, rowerownia („pomieszczenie służące do przechowywania rowerów”), roweroza („mania na punkcie roweru i jazdy na rowerze”), rowerówka („przemysł rowerowy”), roweryk („utwór poetycki o tematyce rowerowej”), rowerysta, roweryzacja, roweryzować, rowerzyca („mania na punkcie roweru i jazdy na rowerze"), rowerzyć, urowerowić, urowerowienie, wyrowerkować („przejechać pewien dystans”), wyrowerować, zarowerkować, zarowerowany („posiadający rower”), zarowerzyć, zrowerować, zroweryzować, zrowerzony itd. (zob. Wiertlewski 2016a). Widać tutaj, jak i w części wcześniej przywołanych przykładów, dużą łatwość w tworzeniu form pochodnych. Można wręcz zaryzykować twierdzenie, że omawiana środowiskowa odmiana języka jest o wiele bardziej podatna na wszelakie adaptacje, także morfologiczne, od odmiany ogólnej języka polskiego.

Znaczącą aktywność słowotwórczą skutkującą licznymi derywatami wykazują też np. leksemy bike i biker, o czym świadczą następujące przykłady: bajkować, bikeować, bike'ować, bikeowiec, bikeowy, bike'owy, 
bikerka, bikerowy, bikerski, bikerstwo, bikerzyca, bikować, bikowy, bikerowanie, pobikować, przebikować. Podobnie jest w przypadku leksemu enduro, który stał się podstawą następujących jednostek (także zrostów): endurance'owy, enduracki, enduractwo, endurak, enduroholic, enduroholizm, enduromania, enduromaniak, endurowaty, endurowiec, endurowy, endurowyrypa, endurówka, enduryzacja. Generalnie mówiąc, znacząca część zapożyczonej leksyki jest bardzo aktywna morfologicznie, a jej zdecydowana większość odmienia się według polskich paradygmatów fleksyjnych. Jednostkami, które jednak nie odmieniają się są np. all-round, big air, bottom pull, chicken line, coffee ride, core, enduro, epo, face plant, flow, frameset, headset, hucking, minimal gains, reach, recovery, rege, skid, stack.

W zarejestrowanym przeze mnie materiale są również zapożyczenia morfologiczne, takie jak prefiksy super- (np. superbiker, super-depnięcie, supermaraton, supersprawny, superrowerowy, superwaleczny) czy ultra(np. ultrabiker, ultrakolarski, ultrakolarz, ultralekki, ultralight, ultramaraton, ultramaratończyk, ultraobciążenia, ultrapoświęcenie, utrastromy, ultrasztywny, ultrawysitek, ultrawyścig, ultrawyzwanie). Pojawiają się również sufiksy -(o)holic (np. enduroholic, roweroholic, szosoholic) i -ing (np. jaming, rowering), co potwierdza obserwacje Waszakowej (2005: 54-55) o internacjonalizacji mechanizmów słowotwórczych we współczesnym języku polskim. Z kolei, wątpliwości klasyfikacyjne (np. Burkacka 2010: 231) dotyczące statusu struktur złożeniowych budzą przypadki w rodzaju ekorower, czy z formą $e^{-}$„uciętą od angielskiego przymiotnika electronic" (Witalisz 2016: 155), np. e-biker, e-bike'owiec, e-doping, e-maszyna, e-rower, e-sprinter, e-szosa, euczestnik. Pytanie, którego nie da się łatwo rozstrzygnąć, brzmi, czy są to composita, czy też derywaty słowotwórcze. Witalisz (2016: 136) proponuje nazywać je pseudoprefiksami i pseudoafiksami. Kwestia ta dotyczy również wspomnianego powyżej ultra-, który, jak pokazałem, pojawia się jako samodzielny rzeczownik (ultra, ultras).

$\mathrm{Na}$ marginesie warto dodać, że przywołane w niniejszym tekście anglicyzmy właściwe to (zob. Witalisz 2016: 37 - 39): 1. zapożyczone leksemy proste (np. bike, box, carbon, fat, full, gravel, jam, peg, single, street, trail), 2. zapożyczone derywaty (np. biker, chopper, drafting, fitting, jumping, rider, rover, ultrabiker), 3. zapożyczone złożenia (np. bikefitting, bikejumping, carbosnack, flatland, headset, jumpbox, lockring, mindset, messlife, motodoping, pumptrack, rockring), 4. zapożyczone zestawienia i związki frazeologiczne (np. alley cat, chicken line, full face, mariginal gain, snake bite, wheel base), 5. zapożyczone akronimy (np. AM - all mountain, $A R$ - adventure racing, $A T B$ - all terrain bike, BMX - bicycle motor cross, $C C$ - cyclocross, $D H$ - downhill, $D J$-dirt jumping, DNF - did not finish, $D S$ - dual slalom, ED - enduro, epo - erythropoietin, $F R$ - free ride, $H T$ - hard tail, FS - full suspension, MIPS - multi-directional impact protection system, SAG - support and gear, SID - superlight integrated design, SIS Shimano Indexing System, SPD - Shimano Pedaling Dynamics, STW stiffness-to-weight, TB - triple butted, TT - time trial, VPP - virtual pivot 
point, WS - women special, XCE - cross country eliminator, XCO - cross country olympic, XCM - cross country marathon).

Przedstawiona w artykule leksyka środowiskowa, głównie w postaci rzeczowników, pod względem różnorakich procesów w niej zachodzących nie odbiega od tego, co ma miejsce w polszczyźnie ogólnej. Na przykład, obserwujemy tu mechanizm seryjnego tworzenia nazw adoptowanych $\mathrm{i}$ derywowanych, co jest charakterystyczną cechą współczesnego słowotwórstwa (Bajerowa 2005: 65). Widzimy to np. w przypadku określeń kolarzy różnych specjalności: bmxowiec, crosscountrowiec, dirtowiec, downhillowiec, dualowiec, e-bikowiec, endurowiec, fatbikowiec, flatlandowiec, fourcrossowiec, freeridowiec, gigowiec, grandtourowiec, mountainbikowiec, streetowiec, trailowiec, trailsowiec, uphillowiec czy nazw typów rowerów, np. dirtówka, dualówka, endurówka, fourcrossówka, freerajdówka, gravelówka, grejwelówka, karbonówka, krossówka, treningówka, trialówka, uphillówka. Nie jest tė̇ niczym wyjątkowym pojawiające się tu zjawisko depluralizacji (Mańczak-Wohlfeld 2006: 63), którego ilustrację stanowią np. barendsy, bikepackersi, cantisy, combosy, localesi, mastersi, partsy, prosi, ridersi. Pewną ciekawostką jest natomiast fakt występowania w cyklolekcie par synonimów zapożyczonych $\mathrm{z}$ różnych języków, np. bicykl - bike, cyngle - manetki, domestique gregario, koks - doping, gravel - szutrówka, profi - pros, spurt - sprint. Z kolei, podobnie jak w odmianie ogólnej, częste jest zjawisko wieloznaczności w postaci homonimii i polisemii (zob. Wiertlewski 2016a), co prezentują np. belka, blok, booster, combo, cyngle, dirt, drop, flow, full, jump, kapsel, klasyk, klocek, koks, nypel, piwot, szosa, trekking, uphill, wachlarz..

Zwraca również uwagę fakt, że w części nie jest to leksyka w pełni ustabilizowana, o czym świadczy spora liczba wariantów (dotyczy to wyłącznie zapożyczeń angielskich) konkretnych jednostek leksykalnych odmiennie adoptowanych graficznie i fonologicznie (np. bik, fatbrejki, grejvel, rajder), przy czym nie jest to wyłącznie właściwość leksyki środowiskowej (zob. Mańczak-Wohlfeld 2004: 3-7). Mamy tu więc takie pary dubletowe, jak np. bike - bajk, biker - bajker, carbon - karbon, cartridge - kartridż, double - dable, gravel - grejwel, lycra - lajkra, rider rajder, trick - trik. Panuje też zamieszanie odnośnie do pisania nazw łącznie lub rozłącznie, np. alley cat - alleycat, dirt jumper - dirtjumper, full face fullface, fun bike - funbike, grip shift - gripshift. Jako osobny przypadek należy potraktować parę suport („część mechanizmu korbowego”) i selfsupport („wyścig bez wspomagania z zewnątrz”), gdzie odmienna pisownia oznacza różne znaczenia.

Konkludując, przywołane powyżej przykłady leksyki, prawie wyłącznie środowiskowej, potraktowane łącznie pokazują rzeczywiście znaczące nasycenie cyklolektu zapożyczeniami, zwłaszcza pochodzenia angielskiego i stanowią nieco ponad $10 \%$ zgromadzonego przeze mnie zasobu leksykalnego omawianej odmiany języka. W zaprezentowanym materiale liczącym łącznie z wariantami ok. 700 jednostek, przeważającą większość (prawie 600) stanowią zapożyczenia angielskie $i$ ich derywaty słowotwórcze. Jest to adoptowana na różne sposoby głównie leksyka 
nominacyjna, w dużej mierze nazywająca elementy rzeczywistości świata kolarskiego, dla których w zdecydowanej większości przypadków nie istnieją rodzime odpowiedniki. Objaśnienia ich znaczeń w języku polskim niejednokrotnie, jak pokazałem powyżej, przyjmują bardzo rozbudowaną postać, co ewentualnie w przypadku ich używania byłoby niekorzystne dla ekonomii komunikowania się. Jest to zatem materiał językowy niezbędny, ale jednocześnie także przydatny w budowaniu więzi grupowej na zasadzie, że osoby utożsamiające się ze środowiskiem kolarskim są w jakimś stopniu z nim zaznajomione i nim się posługują, odróżniając się od tych, którzy tej wiedzy i umiejętności nie posiadają. Ponadto, mimo liczebności, przywołane zapożyczenia generalnie "nie rzutują na normę językową polszczyzny” (Mańczak-Wohlfeld 2017: 217). Dodam, że w związku ze zmianami technologicznymi, wprowadzaniem nowych konkurencji kolarskich itp. jest to, jak się wydaje, proces ciągły, co oznacza, że również w bliższej i dalszej przyszłości należy oczekiwać kolejnych pożyczek, zwłaszcza angielskich, w interesującym nas obszarze. Takimi stosunkowo niedawnymi zapożyczeniami są np. airbike, dropper endurance, fatbike, gravel, traclocross, czy drafting - ten ostatni w związku ze znaczącą popularnością triathlonu. Częściowo napływ niektórych zapożyczeń jest spowodowany liczniejszą obecnością polskich kolarzy w zespołach zagranicznych, co powoduje przenoszenie na grunt krajowego środowiska kolarskiego nowych określeń używanych w międzynarodowym peletonie i ich popularyzowanie przez periodyki rowerowe czy komentatorów telewizyjnych (np. domestique, gregario, grupetto, palmares). Jednocześnie zwraca uwagę łatwość, z jaką owe zapożyczenia są adoptowane fonologicznie, graficznie, morfologicznie i semantycznie do systemu języka polskiego w jego socjalnej odmianie, co świadczy o dużej elastyczności i żywotności polszczyzny. 
Stefan Wiertlewski: Zapożyczenia leksykalne w cyklolekcie

\section{Bibliografia}

Bajerowa I. 2005. Zarys historii języka polskiego 1939 - 20oo. Warszawa: Wydawnictwo Naukowe PWN.

Bańko M. (red.) 2005. Wielki stownik wyrazów obcych, Warszawa: Wydawnictwo Naukowe PWN.

Burkacka I. 2010. Klasyfikacja słowotwórcza nowszych zapożyczeń, Linguistica Copernicana 2(4), str. $229-239$.

Haugen E.1950. The analysis of linguistic borrowing, Language 26, str. 210 - 231.

Łaziński M. (red.). 2008. Stownik zapożyczeń niemieckich $w$ polszczyźnie. Warszawa: Wydawnictwo Naukowe PWN.

Mańczak-Wohlfeld E. 1994. Angielskie elementy leksykalne $w$ języku polskim. Kraków: Universitas.

Mańczak-Wohlfeld E. 1995. Tendencje rozwojowe wspótczesnych zapożyczeń angielskich w języku polskim. Kraków: Universitas.

Mańczak-Wohlfeld E. 2004. Fonetyka zapożyczeń angielskich w polszczyźnie XXI wieku, Poradnik Językowy 3, str. 3- 7 .

Mańczak-Wohlfeld E. 2006. Angielsko-polskie kontakty językowe. Kraków: Wydawnictwo Uniwersytetu Jagiellońskiego.

Mańczak-Wohlfeld E. (red.) 2010. Stownik zapożyczeń angielskich $w$ polszczyźnie. Warszawa: Wydawnictwo Naukowe PWN.

Mańczak-Wohlfeld E. 2017. Norma językowa w kontekście kontaktów językowych, Biuletyn PTJ LXXIII, str. 211 - 219.

Markowski A. 1992. Leksyka wspólna różnych odmian polszczyzny, tom 1. Wrocław: Wydawnictwo Wiedza o Kulturze.

Waszakowa K. 2005. Przejawy internacjonalizacji $w$ stowotwórstwie wspótczesnej polszczyzny. Warszawa: Wydawnictwo Uniwersytetu Warszawskiego.

Wiertlewski S. 2006. 'Grindowanie na pegach', czyli o zapożyczeniach angielskich w socjalnej odmianie języka, Język, Komunikacja, Informacja 1, str. $67-76$.

Wiertlewski S. 2016a. Wiele słów, niewiele znaczeń? Synonimia i homonimia/polisemia w socjolekcie rowerowym, Język, Komunikacja, Informacja 11, str. $73-85$.

Wiertlewski S. 2016b. Rower i jazda rowerem z perspektywy metafory konceptualnej, w: A. Czapla, M. Koper (red.), Język $i$ sport, Lublin: Fotopia, str. $133-148$.

Witalisz A. 2007. Anglosemantyzmy w języku polskim - ze stownikiem, Kraków: Tertium.

Witalisz A., 2015. English Loan Translations in Polish. Formation Patterns, Lexicalizations, Idiomaticity and Institutionalization. Frankfurt am Main: Peter Lang.

Witalisz A. 2016. Przewodnik po anglicyzmach w języku polskim, Kraków: TMJP. 